\title{
KASUS-KASUS PEMBANGUNAN RUMAH IBADAT PASCA PBM NOMOR 9 DAN 8 TAHUN 2006 DI PROVINSI SULAWESI UTARA
}

\author{
Sabara \\ Balai Litbang Agama Makassar, Sulawesi Selatan \\ barackfilsafat@yahoo.co.id \\ Artikel diterima 23 April, diseleksi 23 Mei, dan disetujui 25 Juni 2018
}

\begin{abstract}
This study aims at describing the development of the construction of worship houses and cases related to the construction of worship houses in North Sulawesi. The research questions include: how is the development of the construction of worship houses after the PBM No. 8 and 9 (2006) in the province of North Sulawesi? How is the progress of cases related to the construction of worship houses after the PBM No. 8 and 9 (2006)? The construction of worship houses in North Sulawesi experiences significant development even after the issuing of PBM No. 8 and 9 (2006) which more strictly manage matters related to the construction of worship houses. The development of the construction of worship houses take place in all existing religions. There are some cases that relates to the construction of worship houses that it linked to the content of PBM No. 8 and 9 (2006), among others, Al-Khairiyah Mosque, Manado, the rejection of the construction of great mosque in Bitung city, and severl cases of rejections of the construction of mosques in some places in North Sulawesi.
\end{abstract}

Keywords: Worship Houses, PBM No. 8 and 9 (2006), North Sulawesi, FKUB.

\section{PENDAHULUAN}

Pembangunan rumah ibadat merupakan salah satu masalah yang dapat mengganggu terwujudnya kerukunan umat beragama. Masalah tersebut muncul antara lain karena belum adanya kejelasan mengenai persyaratan dan tata-cara pendirian rumah ibadat, proses perizinan pendirian rumah ibadat sering berlarut-larut, penyalahgunaan

\begin{abstract}
Abstrak
Penelitian ini bertujuan mendeskripsikan perkembangan pembangunan rumah ibadat dan kasus seputar pendirian rumah ibadat di Sulawesi Utara. Adapun rumusan masalah dalam penelitian ini adalah: Bagaimana perkembangan pembangunan rumah ibadat pasca PBM Nomor 9 dan 8 tahun 2006 di Provinsi Sulawesi Utara? Dan bagaimana kasus-kasus seputar pendirian rumah ibadat di Sulawesi Utara pasca PBM Nomor 9 dan 8 tahun 2006? Pembangunan rumah ibadat di Sulawesi Utara mengalami perkembangan yang cukup berarti meski telah terbit PBM Nomor 9 dan 8 tahun 2006 yang lebih ketat mengatur persoalan pendirian rumah ibadat. Perkembangan pendirian rumah ibadat tersebut terjadi pada rumah ibadat semua agama yang ada. Ada beberapa kasuskasus terkait pendirian rumah ibadat yang dikaitkan dengan muatan PBM Nomor 9 dan 8 tahun 2006, diantaranya masalah mesjid al-Khairiyah Manado, penolakan pendirian mesjid raya di Kota Bitung, serta beberapa kasus penolakan pembangunan mesjid di beberapa tempat di Sulawesi utara.
\end{abstract}

Kata Kunci: Rumah Ibadat, PBM Nomor 9 dan 8 tahun 2006, Sulawesi Utara, FKUB

rumah tinggal atau bangunan lain yang difungsikan sebagai rumah ibadat, pendirian atau keberadaan rumah ibadat yang tidak sesuai dengan prosedur yang berlaku dan tidak sesuai dengan aspirasi masyarakat setempat (Kustini, 2009:1).

Untuk mengatur permasalahan tentang pendirian rumah ibadat, Pemerintah telah menerbitkan Peraturan Bersama Menteri Agama dan Menteri Dalam Negeri No. 9 dan 
8 tahun 2006 tentang Pedoman Pelaksanaan Tugas Kepala Daerah/Wakil Kepala Daerah Dalam Pemeliharaan Kerukunan Umat Beragama, Pemberdayaan Forum Kerukunan Umat Beragama, dan Pendirian Rumah Ibadat. Peraturan bersama ini berlaku efektif sejak ditandatangani tanggal 21 Maret 2006 dan berlaku untuk seluruh wilayah Indonesia.

Dari hasil penelitian Puslitbang Kehidupan Keagamaan Tahun 2007 terungkap, bahwa sosialisasi PBM tentang rumah ibadat berpengaruh terhadap pemeliharaan kerukunan umat beragama, yaitu 17,4\% dari sebelas faktor yang dapat menyebabkan ketidak-rukunan (Kustini, 2009:71). Namun, bukan berarti tidak ada masalah di seputar pendirian rumah ibadat pasca berlakunya PBM tersebut.

Meski telah ada PBM tersebut sebagai dasar regulatif yang mengatur pendirian rumah ibadat, pada faktanya di lapangan masih terdapat kasus-kasus yang berkenaan dengan pendirian rumah ibadat. Pada tahun 2009, The Wahid Institut mencatat 21 kasus penyerangan, perusakan, penggerebekan rumah, bangunan, atau tempat ibadat, dan penolakan pendirian rumah ibadat (Saaf, 2010: 5). Center for Religious and Cross Cultural Studies (CRCS) melaporkan hasil pemantauannya terjadi 18 kasus kekerasan terkait rumah ibadat (CRCS, 2009 : 28-31). Hasil pemantauan Kepolisian antara tahun 2008-2010 kasus yang menonjol terkait dengan masalah agama dan rumah ibadat dalam bentuk pengrusakan, penyerangan dan protes dari umat beragama lainnya sejumlah 196 kasus, dengan perincian: tempat ibadat Kristiani 142 kasus (Gereja 59 kasus, rumah tinggal yang dijadikan tempat ibadat 60 kasus, ruko dan gedung lainnya 23 kasus), tempat ibadat Islam 20 kasus, Hindu 6 kasus dan tempat ibadat lainnya 2 kasus. (Saaf, 2010: 4).
SETARA Institute (2010) mengkritisi PBM No 9 dan 8 tahun 2006 karena PBM tersebut telah menjadi landasan pikir, sikap, dan tindakan warga dan aparatus negara yang melakukan tindakan kriminal dan tindakan pelanggaran hak asasi manusia. Oleh karena itu, keberadaan PBM No 9 dan 8 ini menurut SETARA Institute merupakan bentuk diskriminasi terhadap kebebasan beragama dan beribadat yang justru telah diatur dalam UUD 1945 pasal 28E dan pasal 29 ayat 2.

Pada tahun 2011, Puslitbang Kehidupan Keagamaan Badan Litbang Diklat Kementerian Agama RI melakukan penelitian seputar Kasus-kasus Pendirian Rumah ibadat di Kawasan Timur Indonesia (Khusus Rumah Ibadat Umat Islam). Penelitian tersebut dilakukan di 5 provinsi, yaitu Sulut, Bali, NTT, Papua, dan Papua Barat. Penelitian tersebut menemukan 20 kasus penolakan pendirian rumah ibadat di 5 provinsi tersebut. Masih hangat pula dalam sajian berita tentang GKI Yasmin di Bogor, yang izin pendiriannya dicabut oleh pemerintah setempat, ada juga kasus penolakan pendirian gereja di kabupaten Pangkep, Sulsel. Melihat fakta-fakta tersebut, tentunya muncul pertanyaan, kenapa setelah pemerintah menerbitkan regulasi terkait pendirian rumah ibadat, masih saja ada kasus-kasus terkait pembangunan rumah ibadat?. Apakah PBM No 9 dan 8 masih belum terlalu efektif berjalan

Sulawesi Utara yang diambil sebagai lokasi peneltian ini, merupakan daerah dengan pluralitas penganut agama yang cukup tinggi. Manado, sebagai ibukota provinsi dijuluki sebagai kota "seribu gereja" (Makkelo, 2010), namun populasi penganut agama lain juga cukup signifikan, demikian pula jumlah rumah ibadat mereka. Pluralitas penganut agama 
ini tentu saja berimplikasi langsung pada pluralitas rumah ibadat berdasarkan agama di Sulawesi Utara. Persoalan rumah ibadat ini kerap menuai berbagai permasalahan atau kasus seputar pendirian rumah ibadat tertentu. Provinsi Sulawesi Utara juga dikenal sebagai ikon kerukunan umat beragama, dan hal ini sebagaimana dikuatkan oleh penelitian Balai Litbang Agama Makassar tahun 2011 tentang potret kerukunan umat beragama di Provinsi Sulawesi Utara.

Menurut Kamus Besar Bahasa Indonesia (2008: 1227) Rumah ibadat adalah rumah tempat beribadat (mesjid, gereja, kuil, dan sebagainya). Hak untuk menjalankan ibadah di tempat ibadat juga merupakan kebebasan beragama yang berdimensi individual maupun komunal. Hal tersebut dijamin secara yuridis oleh UU No. 12 Tahun 2005 yang menyatakan bahwa hak setiap warga negara untuk melakukan ritual dan menjalankan ibadah di rumah atau tempat ibadat masing-masing sesuai dengan keyakinannya, dan ini tidak boleh dibatasi oleh negara. Intinya hak atas kebebasan beragama dalam dimensi individu adalah hak atas keyakinan keagamaanya, dan menjalankan ibadah secara privat.

Sebagai bagian dari ruang lingkup kebebasan beragama, persoalan pendirian rumah ibadat masih menjadi persoalan yang cukup pelik dan rumit. Kendati aturan main sudah dibuat, praktik di lapangan masih menyisakan berbagai persoalan yang kompleks. Dalam hal ini perlunya pemahaman bahwa persoalan pendirian rumah ibadat bukanlah berada dalam ruang kosong. Ia harus menjadi bagian dari komunitas sosial (masyarakat) yang terkadang tidak identik dengan pemeluknya, tetapi lebih luas lagi ia berada dalam tatanan ruang sosial dan psikologis sekaligus karena menyangkut hajat hidup orang banyak. Sehubungan dengan hal tersebut maka sangat tepat apabila pendirian rumah ibadat harus mendapat dukungan sosiologis masyarkat setempat. Inilah kultur Indonesia bahwa HAM tidaklah mengejawantah dalam hak asasi yang sifatnya mutlak tetapi harus berpadu dan beriringan dengan kewajiban asasi untuk menjaga harmonisasi sosial dan ketertiban umum. Hal ini didasarkan bahwa pendirian rumah ibadat secara fisik berkaitan dengan kepentingan umum terutama peruntukan sebuaah lokasi yang dikaitkan dengan berbagai kepentingan termasuk tata ruang.

Dalam rangka mengatur masalah pendirian rumah ibadat, pada masa lalu Pemerintah telah mengeluarkan Surat Keputusan Bersama Nomor 1 Tahun 1969 tentang Pelaksanaan Tugas Aparatur Pemerintah dalam Menjamin Ketertiban dan Kelancaran Pelaksanaan Pengembangan dan Ibadat Agama oleh Pemeluk-Pemeluknya. Namun, dalam pelaksanaan di lapangan masih tetap ditemui berbagai kendala. Hal itu terjadi karena beberapa faktor, antara lain dalam SKB terdapat kalimat multitafsir sehingga tidak ada kejelasan siapa yang disebut pemerintah daerah, tidak adanya kejelasan siapa yang disebut "pejabat pemerintahan di bawahnya yang dikuasakan untuk itu", tidak adanya kejelasan siapa yang disebut organisasi keagamaan dan ulama/ rohaniawan setempat, serta apa yang dimaksud dengan kata-kata "planologi " dan "kondisi dan keadaan setempat". Masalah pendirian rumah ibadat ini kembali mencuat khususnya pada akhir tahun 2004 dan awal tahun 2005. Pro dan kontra di masyarakatpun terkait keberadaan SKB tersebut terlihat di berbagai media massa. Sebagian pemuka agama mengusulkan SKB tersebut dicabut, sementara sebagian 
pemuka agama lainnya mengusulkan untuk tetap dipertahankan (Kustini, 2009; 3).

Untuk merespon permasalahan ini, pemerintah (Departemen Agama dan Departemen Dalam Negeri) bersama majelis-majelis agama (MUI - PGI KWI - PHDI - WALUBI) telah sepakat bahwa masalah pengaturan pendirian rumah ibadat yang sebelumnya berlaku, perlu ditata ulang. Melalui proses pembahasan dan dialog yang relatif intensif, serius, dan berulang-ulang, selama lebih kurang enam bulan, berhasil mencapai kesepakatan, yang kemudian dituangkan dalam "Peraturan Bersama Menteri Agama dan Menteri Dalam Negeri tentang Pedoman Pelaksanaan Tugas Kepala Daerah/Wakil Kepala Daerah dalam Pemeliharaan Kerukunan Umat Beragama, Pemberdayaan Forum Kerukunan Umat Beragama dan Pendirian Rumah Ibadat (PBM Nomor 9 dan 8 Tahun 2006).

PBM Nomor 9 dan 8 tahun 2006 tersebut ditetapkan dan efektif berlaku sejak tanggal 21 Maret 2006 dan ditandatangani oleh M. Maftuh Basyuni selaku menteri agama dan Mohammad Ma'ruf selaku menteri dalam negeri. PBM tersebut terdiri atas 10 bab dan 31 pasal yang secara umum mengatur tiga hal pokok, yaitu; plelaksanaan tugas kepala daerah/wakil kepala daerah dalam pemeliharaan kerukunan umat beragama, pemberdayaan FKUB, dan pendirian rumah ibadat.

Pemberlakuan PBM tersebut untuk keperluan pengaturan rumah ibadat dan bukan sebagai bentuk intervensi negara atau pemerintah terhadap agama, melainkan regulasi yang bersifat pengadministrasian dalam pembangunan rumah ibadat (lihat Asry,
2010; 4). Masih saja terdapat sorotan dan kritikan dari berbagai pihak terkait muatan PBM tersebut, khususnya pasalpasal yang mengatur tentang pendirian rumah ibadat. SETARA Institute (2010) menyebutkan bahwa PBM tersebut sangat sarat dengan muatan diskriminatif dalam pendirian rumah ibadat, khususnya bagi penganut agama minoritas.

Persoalan rumah ibadat dalam PBM Nomor 9 dan 8 tahun 2006dibahas dalam 3 Bab dan 10 pasal, yaitu Bab IV (Pendirian Rumah Ibadat) mulai dari pasal 13 hingga pasal 17, Bab V (Izin Sementara Pemanfaatan Bangunan Gedung) dari pasal 18 hingga pasal 20, dan Bab VI (Penyelesaian Perselisihan) pasal 21 dan 22.

Dalam pasal 13 disebutkan (1) Pendirian rumah ibadat didasarkan pada keperluan nyata dan sungguhsungguh berdasarkan komposisi jumlah penduduk bagi pelayanan umat beragama yang bersangkutan di wilayah kelurahan/desa. (2) Pendirian rumah ibadat sebagaimana yang dimaksud pada ayat (1) dilakukan dengan tetap menjaga kerukunan umat beragama, tidak mengganggu ketentraman dan ketertiban umum, serta memenuhi aturan perundang-undangan. (3) Dalam hal keperluan nyata bagi pelayanan umat beragama sebagaimana dimaksud ayat (1) tidak terpenuhi, pertimbangan jumlah komposisi penduduk digunakan batas wilayah kecamatan atau kabupaten/kota atau provinsi.

Mengenai syarat pendirian rumah ibadat diatur dalam pasal 14, yaitu; Pendirian rumah iabdat harus menenuhi persyaratan administratif dan persyaratan teknis bangunan gedung (ayat 1). Adapaun syarat-sayaratnya adalah memiliki pengguna yang ditandai 
dengan KTP pengguna yang disahkan oleh pejabat setempat, dukungan masyarakat setempat paling sedikit 60 orang yang disahkan oleh lurah/ kepala desa, rekomendasi tertulis kepala departemen agama kabupaten/kota, dan rekomendasi tertulis FKUB kabupaten/ kota. Jika syarat dukungan paling sedikit 60 orang warga setempat tidak terpenuhi, maka PBM mewajibkan kepada pemerintah setempat untuk memfasilitasi tersedianya lokasi pembangunan rumah ibadat (pasal 14 ayat 3).

Mengenai pemanfaatan sementara bangunan gedung sebagai rumah ibadat sementara diatur dalam pasal 18 ayat (3) dengan ketentuan syarat; izin tertulis dari pemilik bangunan, rekomendasi tertulis dari kepala desa/lurah, pelaporan tertulis kepada FKUB kabupaten/kota, dan pelaporan tertulis kepada kepala kantor kementerian agama kabupaten/ kota. Surat keterangan pemberian izin sementara tersebut sebagaimana diatur dalam pasal 19 ayat (2) diberikan paling lama dua tahun.

Berdasarkan asumsi teoritik, serta data awal dan fakta pluralitas keberagamaan dan rumah iabdat di provinsi Sulawesi utara. Maka, hal ini merupakan hal menarik untuk dilakukan penelitian lebih lanjut terkait kasuskasus pembangunan rumah ibadat pasca PBM Nomor 9 dan 8 tahun 2006 di Sulawesi Utara dalam sebuah riset yang serius. Adapun rumusan masalah dalam penelitian ini adalah: 1) Bagaimana perkembangan pembangunan rumah ibadat pasca PBM Nomor 9 dan 8 tahun 2006 di Provinsi Sulawesi Utara? 2) Bagaimana kasus-kasus seputar pendirian rumah ibadat di Sulawesi Utara pasca PBM Nomor 9 dan 8 tahun 2006?

\section{METODE}

Tulisan ini dihasilkan dari penelitian yang menggunakan pendekatan kualitatif. Pendekatan kualitatif digunakan untuk mengeksplorasi kasuskasus berkenaan dengan pembangunan rumah ibadat, termasuk mengksplorasi faktor pendukung, penghambat dan halhal yang membutuhkan kofirmasi data yang bersifat kualitatif untuk kemudian dieksplorasi secara mendalam.

Sebagai penelitian kualitatif, maka penelitian ini menggunakan tiga metode (Patton, 2006: 3), yaitu wawancara mendalam, observasi lapangan, dan pemanfaatan dokumen tertulis maupun gambar dan video. Selain itu untuk melengkapi dan sekaligus mengkonfirmasi data yang didapatkan, peneliti juga menggunakan Focus Group Discussion (FGD) sebagai salah satu kiat untuk memperoleh data yang valid.

Penelitian ini adalah penelitian berbasis rumah ibadat yang berdiri pasca PBM Nomor 9 dan 8 tahun 2006. Oleh karena itu, penelitian ini adalah masyarakat yang berbasis rumah ibadat. Penentuan informan untuk penelitian kualitatif dilakukan dengan cara purposive (Kasniyah, 2012: 7). Informan kunci diambil dari pelaksana pendirian rumah ibadat, tokoh-tokoh agama, pengurus FKUB, serta kementerian agama. Analisis data kualitatif dilakukan dengan metode analisis deskriptif tapi kritis. Data dijelaskan dengan mengaitkan berbagai realitas yang berkenaan dengan kasus pembangunan rumah ibadat pasca PBM. Waktu penelitian ini dilaksanakan selama 22 hari. Penelitian ini mengambil lokasi di kota Manado dan kota Bitung Provinsi Sulawesi Utara. 


\section{HASIL DAN PEMBAHASAN}

\section{Selayang Pandang Sulawesi Utara}

Provinsi Sulawesi Utara adalah provinsi dengan wilayah terletak di ujung utara Pulau Sulawesi mulai sebagian pesisir laut Sulawesi di sebelah Utara dan Barat dan pesisir teluk Tomini di sebelah Selatan, serta pesisir laut Maluku di sebelah Timur. Wilayah membentang hingga kepulauan Nusa Utara yang diantaranya berbatasan dengan negara Filipina di sbelah Utara. Secara astronomis, provinsi Sulawesi Utara terletak pada titik koordinat $00^{\circ} 15^{\prime}$ 053' Lintang Utara dan $123^{\circ} 07^{\prime}-127^{\circ}$ $10^{\prime}$ Bujur Timur. Wilayah darat provinsi Sulawesi Utara seluas 14.544,36 $\mathrm{km}^{2}$ dengan batas-batas Laut Sulawesi dan negara Filipina di sebelah Utara, Laut Maluku di sebelah Timur, Teluk Tomini di sebelah selatan, dan provinsi Gorontalo di sebelah Barat.Penduduk Sulawesi Utara berjumlah 2.319.916 jiwa dengan tingkat kepadatan penduduk 159,51 jiwa/ $/ \mathrm{Km}^{2}$. Laju pertumbuhan penduduk pertahun sebesar $1,15 \%$.

Agama Kristen, selaku agama mayoritas memiliki penganut sebanyak 1.540 .296 jiwa atau $61,17 \%$ dari keseluruhan penduduk Sulawesi Utara menjadi mayoritas di 10 kabupaten/kota. Sedangkan Islam menjadi agama terbesar kedua dengan jumlah penganut sebanyak 802.671 jiwa atau $31,88 \%$ dari jumlah penduduk Sulawesi utara, merupakan agama mayoritas di 5 kabupaten/kota dan memiliki populasi yang signifikan di kota manado dan kota Bitung. Katolik sebagai agama terbesar ketiga dengan jumlah penganut 152.054 jiwa atau 6,04\% dengan persentase tertinggi di Kota Tomohon dan Kabupaten Minahasa. Penganut agama Hindu yang merupakan pendatang dari Bali berjumlah 18.812atau 0,75\% dan sebagian besar bermukim di kabupaten Bolaang Mongondow. Agama Buddha dianut oleh 3.654 jiwa atau 0,15\% dari penduduk Sulawesi Utara, serta agama Khonghucu dianut oleh 688 jiwa atau 0,03\% dari penduduk Sulawesi Utara. Selain keenam agama tersebut, di Sulawesi Utara, khususnya di daerah Minahasa terdapat komunitas Yahudi dengan jumlah penganut diperkirakan 100-an orang dan memiliki sebuah sinagog sebagai rumah ibadat mereka di Minahasa.

Secara sosiologis, masyarakat Sulawesi Utara terdiri atas berbagai elemen yang heterogen, bukan hanya dari segi agama, melainkan dari segi etnik, kultur, dan bahasa. Setidaknya terdapat tiga etnik besar di Sulawesi Utara yang masing-masing menempati satu kawasan besar di Sulawesi Utara. Ketiga etnik tersebut adalah Minahasa, Bolaang Mongondow, dan Sangihe-Talaud. Dua diantaranya menempati wilayah daratan Sulawesi bagian Utara dan satu lagi, yaitu etnik Sangihe-Talaud menempati wilayah kepuauan di sebelah Utara Sulawesi.

Etnik Bolaang Mongondow didominasi oleh penganut agama Islam menempati wilayah Sulawesi Utara bagian Barat. Etnik Minahasa menempati wilayah Sulawesi Utara bagian Timur dan dominan adalah penganut agama Kristen, kecuali dengan sedikit populasi umat Islam di daerah kampung Jawa Tondano, Minahasa serta sedikit di kota Tomohon. Kepulauan Nusa Utara juga didominasi oleh penduduk dengan agama Kristen, kecuali sedikit penganut Islam dari penduduk asli wilayah Sangihe, terutama di Pulau Peta. Di kepulauan Sangihe juga terdapat kepercayaan yang khas, yaitu Islam Tua. 


\section{Perkembangan Pembangunan Rumah Ibadat pasca PBM di Sulawesi Utara}

Jumlah Rumah Ibadat di Sulawesi Utara

Total rumah ibadat dari enam agama di Sulawesi Utara berjumlah 6.179 buah. Sebagian besar atau 74,87\% rumah ibadat tersebut adalah gereja Kristen dengan jumlah total sebanyak 4.626 buah. Selanjutnya rumah ibadat umat Islam berupa Mesjid dan Mushalla sebanyak $18,32 \%$ dari total rumah ibadat atau 1.132 buah dengan rincian mesjid sebanyak 976 buah dan mushalla sebanyak 156 buah. Gereja Katolik totalnya berjumlah 354 buah atau 5,73\%. Tempat ibadat ketiga agama tersebut, tersebar di seluruh wilayah kabupaten/kota di Sulawesi Utara. Sedangkan untuk rumah ibadat agama Hindu hanya berjumlah 30 buah atau $0,49 \%$ dan tersebar di 2 kabupaten dan 3 kota. Rumah ibadat agama Buddha atau vihara sedikit lebih banyak dari pura, yaitu sebanyak 31 buah atau $0,50 \%$ dengan persebaran di 2 kabupaten dan 4 kota. Sedangkan Klenteng/lithang terdapat 6 buah yang tersebar di 1 kabupaten dan 2 kota. Selain itu, terdapat satu buah rumah ibadat agama Yahudi atau Sinagog yang terdapat di kabupaten Minahasa.

Yang menarik dari distribusi rumah ibadat di Sulawesi Utara adalah gereja Protestan yang dominan di hampir semua kabupaten/kota. Bahkan di kabupaten Bolaang Mongondow yang pemeluk agama Kristen hanya sedikit jumlah gereja lebih banyak dari jumlah mesjid. Di kabupaten Bolaang Mongondow Timur, meski penganut Islam lebih banyak dari penganut Kristen, tapi jumlah gereja Kristen jauh lebih banyak daripada mesjid. Data yang hampir sama juga ditunjukkan dengan banyaknya jumlah gereja di kabupaten Bolaang Mongondow Timur dan Bolaang Mongondow Selatan, serta Kota Kotamobagu, yang meski di daerah tersebut adalah daerah mayoritas Islam.

Laju Pertumbuhan Rumah Ibadat Pasca PBM Nomor 9 dan 8 tahun 2006

Selama 5 tahun terakhir rumah ibadah di Sulawesi Utara mengalami pertambahan sebanyak $10,64 \%$ atau 594 buah dari sebelumnya 5.585 buah pada tahun 2009 menjadi 6.179 pada tahun 2013. Daerah dengan persentase pertambahan rumah ibadah tertinggi adalah kabupaten Bolaang Mongondow Timur, yaitu 27,34\% selama lima tahun terakhir. Sedangkan daerah dengan pertambahan persentase jumlah rumah ibadah terendah adalah Minahasa Selatan yang hanya bertambah sebanyak 1,32\%. Daerah dengan pertambahan jumlah rumah ibadah terbanyak adalah kabupaten Minahasa yaitu selama lima tahun terakhir bertambah rumah ibadah sebanyak 139 buah, sedangkan daerah dengan tingkat pertambahan rumah ibadah paling sedikit selama lima tahun terakhir adalah kabupaten Bolaang Mongondow Selatan yang hanya bertambah sebanyak 5 buah rumah ibadah saja.

Selama lima tahun terakhir terjadi pertambahan jumlah mesjid sebanyak 169 buah atau sebanyak 20,94\%, dari sebelumnya pada tahun 2006 jumlah mesjid sebanyak 807 buah menjadi 976 buah pada tahun 2013. Sedangkan pertambahan mushalla bertambah sebanyak 47 buah atau $43,12 \%$ dari sebelumnya sebanyak 109 mushalla pada tahun 2009 menjadi 156 mushalla pada tahun 2013. Jika ditotal jumlah pertambahan rumah ibadah muslim (mesjid dan mushalla) selama lima tahun terakhir bertambah sebanyak 216 buah atau mengalami laju pertumbuhan $23,58 \%$ selama lima tahun terakhir. Daerah 
dengan laju pertumbuhan pembangunan mesjid selama lima tahun terakhir adalah Bolaang Mongondow dan Minahasa Selatan.

Laju pertambahan dan pertumbuhan gereja Kristen selama lima tahun terakhir adalah sebanyak 358 buah atau bertambah sebanyak $8,38 \%$ antara tahun 2009 hingga 2013. Daerah dengan laju pertumbuhan gereja Kristen paling Tinggi selama lima tahun terakhir adalah kabupaten Minahasa dan kabupaten Minahasa Utara. Adapun gereja Katolik selama lima tahun terakhir hanya mengalami penambahan sebanyak 23 buah atau hanya 6,55\% dari sebelumnya pada tahun 2009 berjumlah 351 buah menjadi 374 buah gereja Katolik pada tahun 2013. Hampir seluruh kabupaten/ kota pertumbuhan jumlah gereja Katolik mengalami stagnasi, yang sedikit terlihat perkembangan di Kota Bitung, Kota Kotamobagu, dan Kabupaten Minahasa Utara.

Jumlah pura atau rumah ibadat agama Hindu selama lima tahun terakhir diSulawesi Utara hanya bertambah 5 buah atau $20 \%$ dari sebelumnya berjumlah 25 buah menjadi 30 buah pada tahun 2013. Namun pada tahun 2009, jumlah rumah ibadat agama Hindu hanya terdapat di tiga kabupaten/kota namun pada tahun 2011 rumah ibadat agama Hindu kemudian bertambah di kabupaten Minahasa dan kota Kotamobagu. Pertambahan dan pertumbuhan rumah ibadah agama Buddha atau Vihara selama 5 tahun terakhir hanya bertambah 4 buah saja atau $14,81 \%$, dari sebelumnya berjumlah 27 buah menjadi 31 buah. Daerah dengan penambahan jumlah rumah ibadat agama Buddha adalah kota Manado bertambah tiga buah dan kota Kotamobagu yang bertambah 1 buah. Rumah ibadat agama Buddha tersebar di enam kabupaten/kota yang ada di Sulawesi Utara.

\section{Kasus-Kasus Seputar Pembangunan Rumah Ibadat di Sulawesi Utara}

Meski secara umum, di Sulawesi Utara pembangunan rumah ibadat mengalami pertumbuhan dan perkembangan dari tahun ke tahun. Namun, dalam perjalanannya masih saja menyisakan beberapa kasus menarik terkait penolakan pendirian suatu rumah ibadat tertentu, khususnya rumah ibadat kaum muslim di tengah mayoritas penganut Kristen.

Sedangkan untuk kasus pembangunan rumah ibadat di kalangan Kristen, adalah persoalan banyaknya tempat ibadat "liar" yang tidak terdata. Banyaknya denominasi dalam Kristen Protestan, mengakibatkan pertumbuhan rumah ibadat "liar" yang bertempat di rumah-rumah pribadi atau rumah ibadat berupa gereja yang tidakterdata danbelum mendaftarkan diri di kementerian agama. Demikian pula persoalan banyaknya denominasi Kristen yang beribadah tanpa "gereja", dalam artian menjadikan gedung pertemuan atau hotel sebagai tempat kebaktian mereka. Persoalan rumah ibadat "liar" ini di kalangan Kristen, kerap menuai resistensi, terlebih jika bertempat di daerah pemukiman yang mayoritas penduduknya adalah umat Islam. Resistensi ini setidaknya pernah terjadi di Kelurahan Katambari, Kota Manado pada awal tahun 2013.

Kasus-kasus terkait rumah ibadat setidaknya peneliti klasifikasi menjadi tiga. Kasus rumah ibadat yang dipermasalahkan karena tidak ada lagi pengguna tempatannya, meskipun mesjid tersebut telah berdiri sejak tahun 1967. Kemudian kasus mesjid yang dipermasalahkan pendiriannya, namun akhirnya melalui langkahlangkah tertentu akhirnya tetap berdiri. Selanjutnya pembangunan mesjid yang

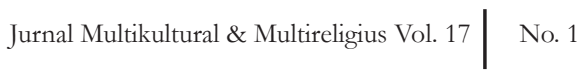


dipermasalahkan oleh masyarakat dan hingga sekarang tidak kunjung berdiri.

Berikut ini, beberapa kasus terkait rumah ibadat pasca PBM di Sulawesi Utara yang sempat peneliti dapatkan datanya melalui beberapa informan.

\section{Kasus Mesjid al-Khairiyah Kota Manado}

Kasus yang terkait dengan Mesjid al-Khairiyah yang terletak di kawasan Boulivard, Kota Manado tidak terkait dengan pembangunan atau pendirian bangunan mesjid. Melainkan gugatan atas eksistensi bangunan mesjid yang tidak lagi memiliki jamaah mukim dikarenakan masyarakat sekitar mesjid telah direlokasi oleh pemerintah kota.

Berawal dari rencana pengembangan kawasan Kota Manado dengan melakukan proyek reklamasi pantai di masa kepemimpinan walikota Jimmy Rimbarogi pada tahun 2007.Sebuah pemukiman di tepi pantai Manado, yang dikneal dengan nama Kampung Texas direlokasi oleh pemerintah Kota. Akhirnya seluruh penduduk di kampung tersebut dipindahkan di pinggiran Kota Manado, seluruh bangunan kemudian dibongkar, terkecuali sebuah bangunan mesjid yang telah berdiri sejak tahun 1967, yang bernama Mesjid al-Khairiyah dan bangunan yang menjadi tempat tinggal imam mesjid yang letaknya masih satu dinding dengan mesjid. Mesjid itu kemudian tetap berdiri dan berfungsi sebagai tempat ibadat meski tidak ada lagi penduduk di sekitarnya, namun emsjid tersebut menjadi tempat ibadah bagi karyawan perkantoran, pedagang, dan orang-orang yang lewat di daerah tersebut.

Pada tahun 2011, oleh pemerintah kota, mesjid tersebut diminta untuk dibongkar, dan pak imam mesjid diminta untuk meninggalkan rumahnya. Pihak pemerintah kota mempersoalkan bahwa mesjid tersebut sudah tidak layak lagi berdiri karena tidak memiliki minimal 90 pengguna sebagaimana yang diatur dalam PBM Nomor 9 dan 8 tahun 2006. Namun, permintaan ini ditolak oleh pak imam dan orang Islam yang ada di sekitar, yang meski bukan jamaah mukim, tapi kerap menggunakan mesjid tersebut untuk menunaikan shalat lima waktu. Secara faktual, mesjid tersebut memang tidak lagi memiliki jamaah mukimin, karena pemukiman di sekitarnya telah mengalami relokasi. Namun, mesjid tersebut tetap aktif digunakan bahkan selalu ramai di setiap waktu shalatnya, terlebih di hari Jumat karena jamaah berasal dari pedagang di sekitar serta karyawan perkantoran, maupun orangorang yang sedang berkunjung di kawasan Boulivard Manado..

Pemerintah kota Manado berencana hendak mendirikan taman wisata religi berupa semua miniatur rumah ibadat (mesjid, gereja, pura, dan vihara) di lokasi tersebut. Namun, rencana ini mendapat penolakan keras dari masyarakat Islam kota Manado. Penolakan tersebut, karena mesjid tersebut tetap berfungsi aktif, bahkan selalu ramai oleh jamaah di setiap waktu shalat. Kemudian untuk mengadvokasi keberadaan mesjid tersebut, kalangan pemuda muslim di kota Manado membentuk Forum Penyelemat Mesjid al-Khairiyah yang diketuai oleh Joko Sutrisno.

Oleh karena, daya tampung mesjid sudah tidak cukup lagiuntuk menampung jamaah, khususnya di waktu shalat Jumat dan di bulan Ramadhan, pengurus mesjid kemudian melakukan perluasan bangunan mesjid, meski renovasi ini tanpa melalui izin dari pihak terkait. 
Pengurus mesjid kemudian berinisiatif untuk mensertifikasi tanah mesjid tersebut atas nama mesjid al-Khairiyah, namun pada tanggal 12 September 2012, terbit sertifikat tanah mesjid tersebut atas nama pemerintah Kota, yang di mana dalam gambar tanah di sertifikat tersebut adalah tanah kosong tanpa bangunan.

Bermodalkan sertifikat tanah dari BPN kota Manado, pemerintah Kota mengajukan proposal pembangunan taman wisata religi kepada Kantor Pusat Kementerian Agama, dan akhirnya mendapat alokasi dana sebesar 15 milyar. Namun, dana tersebut urung cair dikarenakan, kemudian diketahui bahwa di atas tanah loaksi pembangunan taman wisata religi telah berdiri sebelumnya sebuah mesjid.

Di lain pihak, pengurus mesjid dan sebagian elemen pemuda muslim yang dikoordinasi oleh BKPRMI tetap melanjutkan pembangunan perluasan mesjid. Meski mendapat peringatan dari pemerintah kota, pembangunan mesjid tetap terus berjalan. Bahkan suatu hari, tepatnya di hari Minggu, wakil walikota Manado dan camat Wenang Utara beserta beberapa jajaran terkait datang ke loaksi mesjid tersebut untuk meminta penghentian pembangunan mesjid karena tanah tersebut adalah tanah milik pemerintah Kota dan pembangunan mesjid tersebut tidak memiliki IMB. Namun kedatangan wakil walikota beserta jajarannya tidak juga membuat pembangunan mesjid tersebut berhenti. Masalah ini pun kemudian sempat memanasdansangatrentandanberpotensi memicu konflik SARA. Masalah mesjid ini pun sampai terdengar di kementerian agama pusat, dan pada bulan September 2013, wakil menteri agama, Bapak Nazaruddin Umar datang ke mesjid tersebut dan selepas menunaikan shalat
Ashar, beliau memberikan sambutan dan mempermaklumkan bahwa keberadaan mesjid tersebut tidak boleh diganggu gugat.

Hingga kini pembangunan mesjid tetap berjalan, meski proses renovasi bangunan mesjid tersebut dianggap tidak mengikuti prosedur yang berlaku, misalnya perizinan IMB. Pengurus mesjid beralasan, bagaimana mungkin mereka mengurus IMB, sedangkan tanah loaksi mesjid tersebut telah atas nama pemerintah kota, sedangkan pemerintah kota berniat hendak membongkar mesjid tersebut. Akhirnya, dalam pandangan peneliti, kasus mesjid al-Khairiyah ini, dapat menjadi "bom waktu" yang dapat meledakkan kerukunan antar umat beragama, khususnya di Manado, jika pihak-pihak terkait dalam hal ini pemerintah kota dan pengurus serta jamaah mesjid tidak menemui titik temu dalam persoalan ini.

\section{Kasus Pendirian Mesjid Raya Bitung}

Berawal dari kunjungan walikota Bitung Hanny Sondakh ke Banda Aceh pada tahun 2012000,0 di bumi Serambi Mekkah tersebut, walikota Bitung kagum melihat kemegahan dan keindahan Mesjid Raya Baiturrahman di Banda Aceh. Atas kekagumannya itulah kemudian, walikota berniat mendirikan mesjid serupa di kota Bitung.

Sekembalinya di Bitung, walikota kemudian berencana merealisasikan keinginannya tersebut dengan memasukkan ke dalam RAPD tahun 2103 anggaran untuk pembangunan mesjid raya di kota Bitung. Akhirnya dengan persetujuan DPRD, disepakatilah anggaran sebesar Rp. 1 milyar sebagai anggaran untuk pembangunan mesjid 
raya di Bitung. Lahan telah disiapkan dengan luas satu hektar yang merupakan hibah dari seorang pengembang perumahan. Lokasi pembangunan mesjid tersebut terletak di kelurahan Girian Indah, kecamatan Girian.

Pada tanggal 10 )Januari 2013, wakil walikota Bitung, Max, J. Lomban, M. Si beserta ketua DPRD dan beberapa anggota DPRD, kepala Kanwil Kemenag Sulut, kepala Kantor Kemenag Bitung, dan Ketua STAKN Manado beraudiensi langsung dengan Menteri Agama, Suryadarma Ali di ruang kerjanya di gedung Kementerian Agama Jalan $\mathrm{MH}$. Thamrin Jakarta. Dalam audiensi yang diterima langsung oleh Menteri Agama dan beebrapa ditjen terkait di lingkungan Kemenag. Kedatangan rombongan tersebut salah satunya adalah meminta kesediaan Menteri Agama untuk hadir dalam acara peletakan batu pertama Mesjid Raya Bitung yang dijadwalkan pada tanggal 22 Januari 2013, dalam audiensi itu juga pihak STAKN membawa proposal pembangunan Christian Development Centre (CDC).

Rencana pembangunan Mesjid Raya Bitung tersebut ternyata tidak semulus yang dibayangkan, banyak elemen amsyarakat yang menolak pembangunan mesjid tersebut. Puncaknya pada tanggal 17 Januari 2013 Ratusan masyarakat yang dimotori Badan Musyawarah Pemuda Remaja GMIM (BMPRG), Badan Musyawarah Antar Agama (BAMAG) yang mengatasnamakan Gerakan Masyarakat Peduli Kerukunan (GMPK) melakukan aksi di depan gedung DPRD Kota Bitung. menilai rencana pembangunan Masjid RaÂya melanggar Peraturan Bersama Menteri Agama dan Dalam Negeri Nomor 8 dan 9 Tahun 2006. Terutama Bab IV tentang Pendirian Rumah Ibadat. Sebab umat muslim di wilayah pembangunan Masjid Raya hanya sedikit tapi mau dibangun tempat ibadah yang besar. Selain itu menurut aturan daftar nama dan Kartu Tanda Penduduk pengguna rumah ibadah paling sedikit 90 orang yang disahkan pejabat setempat tapi tidak terpenuhi. Selain itu harus ada dukungan masyarakat setempat paling sedikit 60 orang yang disahkan oleh lurah, rekomendasi dari FKUB juga untuk pendirian mesjid tersebut belum terbit. Di ruang rapat gedung DPRD tersebut sedang dilakukan pula rapat dengar pendapat terkait pendirian mesjid tersebut. Rapat yang awalnya tidak dihadiri oleh walikota dan wakil walikota, atas desakan massa yang memaksa untuk menghadirkan kedua pucuk pimpinan kota Bitung tersebut akhirnya keduanya ahdir dalam rapat tersebut.

Setelah melalui perdebatan yang alot dan suasana yang cukup panas, rapat dengar pendapat tersebut akhirnya menghasilkan beberapa rekomendasi. Rekomendasi itersebut ialah, pertama, pembangunan masjid dibatalkan. Kedua, rencana peletakan batu pertama dibatalkan. Ketiga, untuk pembangunan rumah ibadah baru harus berpedoman peraturan Menteri Agama dan Menteri Dalam negeri Nomoar 8 dan 9 Tahun 2006), dan meminta Forum Komunikasi Umat Beragama (FKUB) Bitung tidak merekomendasikan pembangunan rumah ibadah jika tidak sesuai prosedur. Keempat, meminta pihak eksekutif dengan segera menindaklanjuti rekomendasi ini. Sondakh pun saat itujuga langsung menanggapi surat rekomendasi DPRD. Secara tertulis dan lisan Sondakh mengaku menerima rekomendasi tersebut dan akan menindaklanjutinya.

Selain faktor belum terpenuhinya syarat administratif sesuai aturan PBM, penolakan masyarakat, khususnya 
masyarakat non muslim menurut Kepala Kantor Kementerian Agama Kota Bitung, Drs. Ulyas Thaha disebabkan adanya mis komunikasi antar tokoh agama sehingga muncul berbagai perspektif stigmatik terkait pembangunan mesjid tersebut. Penamaan mesjid raya juga disesalkan oleh pak kepala kankemenag, karena penamaan ini identik dengan pembangunan sebuah emsjid yang besar dan tingkatannya provinsi. Selain itu, ada rumor beredar bahwa mesjid yang hendak dibangun adalah mesjid terbesar di indonesia Timur, bahkan terbesar di Asia Tenggara. Hal inilah yang memancing reaksi penolakan, khususnya dari tokoh dan masyarakat Kristen di Bitung.

Akhirnya, pembangunan Mesjid Raya Bitung pun dihentikan, dana satu milyar yang telah dianggarkan dalam APBD Kota Bitung tahun 2013 pun akhirnya dilakukan penjadwalan ulang untuk APBD tahun berikutnya. Dana tersebut kemudian dialokasikan untuk renovasi mesjid al-Muttaqien yang juga terletak di kecamatan Girian.

\section{Kasus-kasus Pendirian Mesjid di Kota Bitung}

Selain kasus terkait pembangunan Mesjid Raya, masih ada beberapa kasus rumah ibadat di Kota Bitung, khususnya mengenai pembangunan mesjid pasca berlaku PBM Nomor 9 dan 8 tahun 2006. Dari beberapa kasus yang peneliti dapatkan saat berkunjung ke Kota Bitung, peneliti memilih tiga diantaranya untuk diangkat dalam tulisan ini. Kedua kasus tersebut mewakili tiga karakteristik, yaitu pembangunan mesjid yang dipermasalahkannamunakhirnya melalui jalur musyawarah dapat berdiri, yaitu mesjid Nurul Taubah kecamatan Girian, tepatnya di depan Kantor Kementerian Agama Kota Bitung. Pembangunan mesjid tersebut dipermasalahkan karena menurut warga sekitar, jumlah pengguna mesjid tersebut tidak cukup 90 orang, dan rumah tepat di samping mesjid adalah milik seorang warga Kristen. Namun, masalah pembangunan mesjid ini dapat teratasi dengan turunnya pihak-pihak terkait dalam hal ini pemerintah dan FKUB, dan pembangunan mesjid tersebut berjalan lancar tanpa penolakan.

Selanjutnya, pembangunan mesjid di kecamatan Matuari, yang awalnya mengalami penentangan, namun akhirnya melalui proses negosiasi pun mesjid tersebut dapat dibangun, namun lokasi emsjid dipindah ke sekitar 50 meter dari arah semula. Meski hanya bergeser sekitar 50 meter, loaksi mesjid yang baru sudah berbeda kelurahan, yang lokasi sebelumnya berada di kelurahan Sagerat, kemudian pindah ke kelurahan Menambo-manembo Atas. Penolakan pendirian mesjid di kelurahan Sagerat, kecamtan Matuari terkait klaim bahwa tanah kelruahan Sagerat adalah tanah adat Minahasa, sehingga tidak boleh dibangun di atasnya sebuah mesjid, meski jumlah pengguna di kelurahan tersebut telah lebih dari 90 orang, sebagaimana yang diatur dalam PBM. Lokasi mesjid yang memang berada di tapal batas kelurahan Sagerat dan kelurahan Manembomanembo Atas, akhirnya disepakati, lokasi pembangunan mesjid bergeser sedikit ke kelurahan Manembo-manembo Atas, namun berbatasan langsung dengan kelurahan Sagerat, dengan demikian jamaah mesjid yang berada di kelurahan Sagerat tetap bisa menggunakan mesjid tersebut sebagai tempat ibadah.

Kasus yang ketiga adalah pembangunan mesjid yang akhirnya terhenti karena mendapat penolakan keras dari warga sekitar. Pembangunan mesjid tersebut direncanakan dibangun 
di atas tanah yang terletak di kelurahan Wangurer kecamatan Girian. Setelah acara peletakan batu pertama yang mengundang pihak-pihak terkait, warga sekitar yang umumnya Kristen menolak pembangunan mesjid tersebut dan secara simbolik esok harinya menancapkan salib di atas tanah lokasi pembangunan mesjid tersebut. Penolakan pembangunan emsjid di loaksi tersebut dikarenakan tidak cukupnya pengguna sebagaimana ketentuan yang diatur dalam PBM serta pendirian mesjid sangat berdekatan dengan gereja, sehingga masyarakat sekitar tidak bisa menerima pembangunan emsjid tersebut. Masalah ini pun nyaris berujung konflik SARA, namun dapat diredam, tapi pembangunan mesjid kemudian terhenti, dan hingga kini tidak dapat dilanjutkan lagi pembangunannya.

\section{Kasus Rumah Ibadat "Liar" Kristen}

Banyaknya rumah ibadat liar di kalangan Kristen Protestan, menjadipersoalan serius yang terus saja dihadapi oleh umat Nasrani hingga kini. Banyaknya denominasi, baik yang lama maupun yang baru, membuat tuntutan akan keberadaan tempat ibadat atau kebaktian bagi mereka semakin tinggi. Karakteristik peribadatan di kalangan Nasrani memang khas, karena perbedaan denominasi meniscayakan untuk tidak saling memasuki tempat ibadat satu sama lain.

Seiring dengan banyaknya denomiansi, dan mucnulnya denominasi baru di kalangan nasrani di Sulawesi Utara, membuat subur munculnya tempattempat ibadat baru. Sayangnya banyak diantara denominasi Kristen tersebut, tidak memiliki gereja dalam bentuk bangunan yang sebagaimana mestinya sebuah bangunan gereja. Tak sedikit diantara mereka yang beribadat dari rumah ke rumah atau menggunakan bangunan publik seperti gedung maupun hotel untuk melaksanakan kebaktian setiap pekannya. Keberadaan jamaah tanpa gereja ini tentu saja merupakan problem serius bagi internal kalangan Kristen.

Selain problem, banyaknya denominasi yang beribadah tidak di gereja fromal. Masalah lain yang mejadi perhatian serius Bimas Kristen adalah banyaknya rumah ibadah liar yang tidak memenuhi persyaratan sebuah bangunan rumah ibadat, dan bahkan tidak terdaftar sebagai rumah ibadat sementara, sebagaimana yang diatur dalam PBM Nomor 9 dan 8 tahun 2006 tentang pemanfaatan bangunan gedung sebagai rumah ibadat sementara.

Persoalan kebaktian tanpa gereja ini, kerap menimbulkan masalah bagi penduduk di sekitar, tak terkecuali di Manado, sebagai sebuah kota yang mayoritas penduduknya adalah penganut Kristen. Friksi antar sekte dan saling "rebutan" jemaat dapat menjadi potensi besar yang mengancam kerukunan interan umat Kristen di Indonesia.

Konflik terkait rumah ibadat "liar" dalam hal ini sebuah bangunan yang difungsikan secara tanpa izin baik dengan pemerintah setempat maupun dengan amsyarakat untuk difungsikan sebagai rumah ibadat. Salah satu contoh masalah ini terjadi pada tahun 2013 di kelurahan Katambari, Manado. Kala itu sebuah rumah milik seorang haji dikontrak oleh seseorang yang ternyata adalah seorang "gembala". Tanpa seizin tuan rumah dan masyarakat sekitar, rumah kontrakan tersebut kemudian menjadi tempat rutin kebaktian mereka (sebuah denominasi dalam Kristen). 
Adanya kebaktian di rumah tersebut, di rasa cukup mengganggu warga sekitar yang mayoitas adalah muslim. Nyaris saja terjadi bentrok antara warga dan jemaat, hingga akhirnya diambil keputusan pendeta yang mengontrak rumah tersebut harus segera meninggalkan rumah tersebut, meski waktu kontrakan rumah tersebut belum habis.

\section{SIMPULAN}

Pembangunan rumah ibadat di SulawesiUtara mengalami perkembangan yang cukup berarti meski telah terbit PBM Nomor 9 dan 8 tahun 2006 yang lebih ketat mengatur persoalan pendirian rumah ibadat. Perkembangan pendirian rumah ibadat tersebut terjadi pada rumah ibadat semua agama yang ada. Ada beberapa kasus-kasus terkait pendirian rumah ibadat yang dikaitkan dengan muatan PBM Nomor 9 dan 8 tahun 2006, diantaranya masalah emsjid al-Khairiyah manado, penolakan pendirian mesjid raya di Kota Bitung, serta ebebrapa kasus penolakan pembangunan mesjid di beberapa temapat di Sulawesi utara.

Masih banyak rumah ibadat yang berdiri tanpa melalui proses sebagai yang diatur dalam PBM, meski sosialisasi telah sering dilakukan menganai muatan PBM, baik oleh Pemda, Kemenag, dan FKUB. Muatan dalam PBM kerap dijadikan dalih untuk menolak atau bahkan menggugat eksistensi bangunan rumah ibadat agama tertentu. Mekanisme kultural ditempuh dalam hal penyelesaian perselisihan terkait pendirian rumah ibadat, hanya saja mekanisme kulturla belum berjalan secara maksimal untuk menyelesaikan perselisihan terkait pembangunan rumah ibadat.

\section{UCAPAN TERIMA KASIH}

Di akhir tulisan ini, penulis sangat berterima kasih kepada Kepala Balai Litbang Agama Makassar serta Kepala Badan Litbang dan Diklat Kementerian Agama RI yang telah memberikan kesempatan kepada penulis untuk melakukan penelitian tentang isu yang diangkat dalam tulisan ini, juga beberapa pihak dan informan yang terlibat dalam penggalian data dan informasi di dalamnya. Tidak ketinggalan, terima kasih juga penulis tujukan kepada Mitra Bestari dan Pengelola Jurnal Harmoni yang telah memberikan catatan dan saran untuk perbaikan tulisan ini, hingga bisa diterbitkan pada Jurnal Harmoni edisi kali ini.

\section{DAFTAR ACUAN}

Ahmadin. Metode Penelitian Sosial. Makasar: Rayhan Intermedia. 2013.

Asry, M. Yusuf. Pendirian Rumah Ibadat di Berbagai Daerah (Pelaksanaan PBM Nomot 9 dan 8 Tahun 2006). Makalah Rangkuman Hasil Penelitian Disampaikan pada Seminar yang Diselenggarakan oleh Puslitbang Kehidupan Keagamaan, Badan Litbang dan Diklat, Kementerian Agama RI Tanggal 2 Agustus 2010 di Jakarta.

Brannen, Julia. Memadu Metode Penelitian: Kualitatif dan Kuantitatif Yogyakarta: Pustaka Pelajar. 2005.

Center for Religious \& Cross Cultural Studies, Laporan Tahunan Kehidupan Beragama di Indonesia 2009, Universitas Gajah Mada Yogyakarta, 2009 
Kasniyah, Naniek. Tahapan Menentukan Informan dalam Penelitian Kualitatif. Yogyakarta: Penerbit Ombak. 2012.

Kustini (ed). Efektivitas Sosialisasi Peraturan Bersama Menteri Agama dan Menteri Dalam Negeri Nomor 9 dan 8 Tahun 2006. Laporan Hasil Penelitian Puslitbang Kehidupan Keagamaan Badan Litbang dan Diklat Kementerian Agama RI. 2009.

Peraturan Bersama Menteri Agama dan Menteri Dalam Negeri Nomor 9 dan 8 tahun 2006 tentang Pedoman Pelaksanaan Tugas Kepala Daerah/ Wakil Kepala Daerah dalam Pemeliharaan Kerukunan Umat Beragama, Pemberdayaan Forum Kerukunan Umat Beragama dan Pendirian Rumah Ibadat.

Pusat Bahasa Depertemen Pendidikan Nasional. Kamus Bahasa Indonesia. Jakarta: Pusat Bahasa Depdiknas. 2008.

Puslibtang Kehidupan Keagamaan. Kasus-kasus Rumah Ibadat di Kawasan Timur Indonesia (Khusus Rumah Ibadat Agama Islam). Laporan Hasil Penelitian. 2011.

SETARA Institute. Lokus Diskrimiansi dalam PBM Dua Menteri. 2010.

Saaf, Saleh, Peran strategis FKUB dalam mendukung kamtibmas dan penyelenggaran pemilukada 2010, Jakarta: Mabes Polri, 2010 